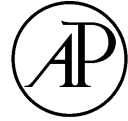

ACADEMIC

PRESS

\title{
How does fiscal decentralization affect aggregate, national, and subnational government size?
}

\author{
Jing Jin ${ }^{\mathrm{c}}$ and Heng-fu Zou ${ }^{\mathrm{a}, \mathrm{b}, \mathrm{c}, *}$ \\ a School of Management, Peking University, Beijing, China \\ ${ }^{\mathrm{b}}$ Institute for Advanced Study, Wuhan University, Wuhan, China \\ ${ }^{\mathrm{c}}$ Development Research Group, The World Bank, Room MC 3-639, 1818 H St. NW, \\ Washington, DC 20433, USA
}

Received 22 January 2001; revised 7 November 2001

\begin{abstract}
Beyond conducting the usual regression analysis of the relationship between fiscal decentralization and aggregate government size (national and subnational combined), this paper makes the first attempt to examine how different fiscal decentralization measures affect the sizes of national and subnational (state and local combined) governments. An econometric analysis using panel data from 32 industrial and developing countries, 1980-1994, finds that (1) expenditure decentralization leads to smaller national governments, larger subnational governments, and larger aggregate governments; (2) revenue decentralization increases subnational governments by less than it reduces national governments, hence leads to smaller aggregate governments; and (3) vertical imbalance tends to increase the sizes of subnational, national, and aggregate governments. () 2002 Elsevier Science (USA). All rights reserved.
\end{abstract}

JEL classification: $\mathrm{H} 5 ; \mathrm{H} 7 ; \mathrm{R} 5$

Keywords: Fiscal decentralization; Size of government; Vertical imbalance; Borrowing constraints

\footnotetext{
* Corresponding author.

E-mail address: hzou@worldbauk.org (H.-f. Zou).
} 


\section{Introduction}

With the dramatic growth of the public sector during the twentieth century, many economists have questioned the effectiveness of the government's role in public service provision and created a presumption in favor of reducing the size of the public sector by giving more power to both the market and local jurisdictions. Fiscal decentralization is seen as a mechanism to control the growth of the public sector and improve the efficiency in public services (see Tanzi [1] for a recent review, and Davoodi and Zou [2] and Zhang and Zou [3] for empirical evidence). It is also proposed as an important element of public-sector reform in developing countries in the last two decades (Bahl and Linn [4], Shah [5], Fukasaku and de Mello [6], and Inman and Rubinfeld [7]).

General discussions center on two important channels through which fiscal decentralization could reduce the size of government-political participation and fiscal (tax) competition. The political participation argument suggests giving citizens and their elected representatives more power in public decision making. Since the local population has strong incentives to discipline local public officials and can monitor the local authorities closely, to the extent that local services are financed by the jurisdiction's own revenue, decentralization can lead to higher civic participation, improved citizen control over the action of the public officials, and a smaller government (Stein [8]).

The fiscal (tax) competition argument suggests decentralization itself is a powerful constraint on the Leviathan: "Competition among governments in the context of the interjurisdictional mobility of persons in pursuit of 'fiscal gains' can offer partial or possibly complete substitutes for explicit fiscal constraints on the taxing power" (Brennan and Buchanan [9]).

But Oates [10] indicates that from the perspective of economies of scale, fiscal decentralization may be relatively expensive in budgetary terms. An even stronger hypothesis suggested by John Wallis (quoted in Oates [10]) is that, since individuals have more control over public decisions at the subnational levels than at the national level, they may empower the local public sector with an even wider range of functions and responsibilities when they are carried out by local levels of government. Thereby, the size of subnational (state and local) governments can be larger, the more decentralized is fiscal decisionmaking.

Despite many efforts by scholars of fiscal decentralization, including Oates's [10], there is no theoretical or empirical consensus on a systematic relationship between fiscal decentralization and the relative size of aggregate public sector (the sum of national and subnational governments). If we consider the effects of fiscal decentralization on national and subnational government size (state and local combined) separately, the relationship at each level may be different. It is obvious that decentralization should increase the size of subnational governments while shrinking the size of the national government. But the effect of fiscal decentralization on aggregate government size cannot be automatically 
determined because it depends on the relative magnitude of its effects on the sizes of subnational and national governments.

This paper extends recent studies on the relationship between fiscal decentralization and government size by taking the following approaches: (1) considering three different measures of fiscal decentralization-expenditure and revenue decentralization, and vertical imbalance-and their different effects on aggregate government size, (2) disaggregating the effects of fiscal decentralization on government size at national and subnational levels (per John Wallis's suggestion), and (3) controlling for political and administrative decentralization in the econometric analyses.

Section 2 reviews theoretical and empirical studies on the relationship between fiscal decentralization and aggregate government size. Section 3 describes our approaches, the panel data set, and the empirical methodology used. Section 4 reports the regression results. Section 5 summarizes the findings and concludes.

\section{Theoretical arguments and existing empirical evidence}

\subsection{Theoretical arguments}

From the perspective of allocative efficiency, various arguments have long been put forward in the public finance literature to support the view that decentralization would lead to greater efficiency and a leaner public sector (Tiebout [11] and Oates [12]). The Leviathan model by Brennan and Buchanan [9] presents the most dramatized theoretical case on how fiscal decentralization can reduce the size of government. In their model, government is a monolithic entity that systematically seeks to maximize fiscal revenues, and it can only be limited by constitutional constraints. In particular, the decentralization of revenue and expenditure assignments can create a market-like solution and therefore limit government's excessive taxing power at the corresponding levels. Furthermore, when mobile individuals seeking maximum fiscal benefits "vote with their feet," this behavior generates competition among jurisdictions. Such competition, which is in line with the Tiebout model, limits a subnational government's excessive taxing power, encourages cost-efficient production and supply of local public goods and services, and thereby, restrains growth of the subnational governments and hence the aggregate public sector. In brief, "total government intrusions into the economy should be smaller, ceteris paribus, the greater the extent to which taxes and expenditures are decentralized" (Brennan and Buchanan [9]). Moreover, introducing elements of competition into the political process could improve governments' responsiveness. With democratic election of government officials at subnational levels, decentralization could increase the accountability of government actions, and endow voters with more power to discipline public officials (Stein [8]). 
Challengers of the Leviathan model outline conditions under which decentralization could be a less attractive policy tool (Prud'homme [13] and Tanzi [1]).

Supply efficiency (economies of scale). For example, Prud'homme [13] argues that (1) the hypothesis that decentralization will better serve the demands generated by diversified preferences only holds if supply is always efficient; and (2) the Leviathan model lacks an emphasis on supply efficiency in the context of economies of scale. If economies of scale in the provision of public services are substantial, decentralization may result in larger government (Stein [8]).

Political participation. The Leviathan model also assumes that taxpayers/voters of each jurisdiction will express their preferences in their votes, and that higher civic participation and better citizen control over the actions of public officials will result in a smaller public sector. According to Prud'homme [13], this hypothesis may not hold for local electoral behavior in developing countries. Where local elections exist, they are usually decided on the basis of personal, tribal, or political party loyalties.

Flypaper effect. Fiscal imbalances bridged with intergovernmental grants can significantly stimulate expenditures by recipient subnational governments (Oates [10,14]; see also Nelson [15] and Zax [16]). Stein [8] comes to a similar conclusion: subnational governments that receive transfers spend them more easily than they spend local tax revenues. The implication is that if a significant part of subnational government spending is financed through transfers from the higher level of government, decentralization could lead to growth in government.

The problem of the commons. This problem arises from a disconnection between beneficiaries of public services and those who pay for them. If revenues remain centralized to a large degree while expenditures are decentralized, and if discretionary transfers bridge such vertical imbalance, the commons problem may be more serious than using a transfer mechanism based on predetermined formula. Because discretionary transfers tend to be allocated to those jurisdictions that are in financial trouble (Stein [8]), subnational governments will overspend in order to ask for additional funds from the national government. Thus, fiscal decentralization with a large discrepancy between subnational revenues and expenditures may be morally hazardous and contribute to the growth of governments.

Soft budget constraints. Soft budget constraints on subnational governments resulting from borrowing autonomy can potentially lead to capital-market debt liabilities being directly or indirectly passed on to the national government. If the national government is always ready to bail out indebted subnational governments, then subnational governments can follow an expansion policy with 
less concern about their ability to pay off the debt. This simple hypothesis of soft budget constraints suggests that borrowing autonomy by subnational governments is associated with increased government sizes. This association could be even more significant when discretionary transfers are involved.

The quality of local bureaucracies. Because national government bureaucracies are more likely to offer qualified people better careers and more possibilities of promotion, and because talented individuals tend to choose fields that offer better opportunities for advancement over the longer run, the resulting poor quality of local bureaucrats is likely to reduce the benefits of decentralization (Prud'homme [13]). For example, the lack of qualified officials at subnational levels may result in weak public expenditure management and higher costs.

Corruption. Prud'homme [13] believes that corruption may be more prevalent at subnational levels for the following reasons: (1) Opportunities for corruption at subnational levels are more likely because politicians and bureaucrats are more accessible and susceptible to pressing demands from local interest groups (whose money and votes count) in matters such as taxation or authorizations. (2) Corruption in many cases requires the cooperation of both politicians and bureaucrats. Such cooperation is more easily aligned at the local level where bureaucrats have less independence from local politicians than national bureaucrats do from national politicians. (3) Local officials usually have more discretion than national decisionmakers. Thus, decentralization may increase the overall level of corruption (see Brueckner [17]).

Tanzi [1] shares the same argument by reasoning that corruption is often stimulated by contiguity, that is, by the fact that officials and citizens live and work close to one another in local communities. When this occurs, the public interest often takes a back seat, and decisions that favor particular individuals or groups are made.

Public expenditure management systems. The necessary elements of good public expenditure management-clear budgetary classifications, an informative accounting system, and skilled people to forecast expected revenues and anticipate spending (Tanzi [1])—are usually missing or insufficient, especially in developing countries and transition economies, and, in particular, at subnational government levels.

\subsection{Existing empirics}

Oates [12], in his earlier empirical study using a cross-section sample of 57 countries, finds that higher fiscal centralization is associated with a smaller public sector. Specifically, he finds a strong and statistically significant negative association between the size of the public sector (measured by tax revenues 
as a fraction of national income) and a fiscal centralization ratio (measured by central government tax revenues as a percentage of total tax revenue). Another test by Oates [14], using a cross-section sample of 43 countries, reaches a similar conclusion. He regresses the size of the public sector (measured by aggregate tax revenue in each country as a fraction of GDP) on central revenue as a fraction of total revenue, and central expenditure as a fraction of total expenditure. His findings do not support the Leviathan hypothesis, but rather suggest that a relatively decentralized public sector is typically comparatively large (Oates [14, p. 754]). Control variables such as income, population, and government transfers, however, contribute to a more powerful explanation for government size than the two measures of fiscal centralization alone.

A mixed picture emerges from empirical studies undertaken since Oates's pioneering efforts. For example, Marlow [18] models the association between decentralization and government size for the United States at the aggregate level (federal and state level combined) using time series data for 1946-1985. He measures aggregate public-sector size by taking total government expenditure as a percentage of GNP. His regression of the aggregate public expenditure on subnational expenditure as a fraction of total government expenditures and two other control variables (real per capita disposable income in 1972 and population), demonstrates that fiscal decentralization is negatively associated with government size.

Grossman [19] explores this relationship in the US data by emphasizing the role of intergovernmental grants, which are supposed to encourage expansion of the public sector by concentrating taxing power in the national government and by weakening the fiscal discipline imposed on subnational governments for financing of their own expenditures. Grossman regresses aggregate government size (total government expenditures as a share of GNP) on expenditure decentralization (the share of state and local expenditures in total government expenditures) and vertical imbalance (measured by the share of federal grants to state and local governments in total state and local receipts). His result supports the Leviathan model and indicates in particular that grants serve to encourage the expansion of the public sector.

From a cross-country, cross-section perspective, Ehdaie's [20] findings support the Leviathan hypothesis: fiscal decentralization (subnational own source revenue over total subnational-national expenditure) is found to have a statistically significant negative impact on government size (subnational-national government expenditures over GDP), whereas transfers to localities (national revenue transfers over total subnational-national expenditure) have a positive impact on government size. As transfers offset the negative impact of decentralization on government size, his study highlights the importance of decentralizing taxing decisions along with expenditure responsibilities. 
More recently, Stein [8] has examined the Leviathan hypothesis by employing cross-section data from 20 Latin American countries and some OECD countries. ${ }^{1}$ In addition to the explanatory variables of fiscal decentralization (i.e., expenditure decentralization, vertical imbalance, and borrowing autonomy), Stein includes other control variables, i.e., level of public debt in 1989, degree of openness of the economy (measured by the share of total exports and imports in GDP), and share of the population over 65 years of age. His regression results for the Latin American case - that decentralized governments tend to be larger — do not support the Leviathan model.

\section{Approaches, data, and methodology}

\subsection{Approaches}

The objective of this research is to enhance our understanding of the relationship between fiscal decentralization and government size from the following aspects:

1. Relative changes of government size at both national and subnational levels. Beyond conducting the usual regression analysis of the relationship between fiscal decentralization and aggregate government size, we examine how decentralization affects the sizes of national and subnational governments. A test only at the aggregate government level cannot distinguish the possible differentiated effects on government size at different levels.

2. Time series. Unlike the cross-section studies by Oates [14], Ehdaie [20], and Stein [8], we add time series for each country in our cross-country regressions to explore the dynamics of the relationship between fiscal decentralization and government size.

3. Variables measuring fiscal decentralization. Three different variables are used to proxy the level of fiscal decentralization: expenditure decentralization, measured as the ratio of subnational to total government expenditure; revenue decentralization, measured as the ratio of subnational own source revenue to total government revenue; and vertical imbalance, measured as the percentage of expenditures at the subnational level financed by central transfers. Our approach explores the effects of these three measures of fiscal decentralization and disaggregates their potential for differentiated effects on government size.

4. Political and administrative decentralization. Although there have been extensive discussions and research about political and administrative decen-

\footnotetext{
${ }^{1}$ A closely related study is Fornasari et al. [21].
} 
tralization, little empirical research has touched upon this issue in the context of fiscal decentralization. We use four variables to capture political and institutional effects on government size:

- Borrowing constraints. The borrowing autonomy of subnational governments can potentially lead to soft budget constraints. As a result, subnational governments may directly or indirectly pass on capital-market liabilities to upper tiers of government. National government bailouts of subnational governments in financial distress undermine the incentives for the latter to behave in a fiscally responsible way. Any prohibition or non-discretionary rules to constrain subnational government access to the financial market would result in less borrowing, which may suggest a reduction in subnational government size.

- Unitary versus federal state. Economic constitutions make a difference. A federal form of government with decisionmaking shared by all levels of government is considered more decentralized in terms of decisionmaking and therefore conducive to greater freedom of choice, political participation, innovation, and accountability. A federal regime with a more decentralized institutional arrangement is supposed to be more efficient and thus lead to smaller government in comparison with a unitary regime.

- Elected vs. non-elected subnational government. Decentralization assumes that the taxpayers/voters will express their preferences through votes and that such voting-with-their-feet behavior would restrain subnational governments' taxing power.

- Lack of independence of the central bank. It is believed that an independent monetary authority is more likely to restrain governments from pursuing short-term expansionary policies, and possibly limit governments' size. Therefore, monetary institutions may also be instrumental to a better fiscal outcome.

5. Inflation. Because government size may be related to revenue and expenditure assignments, inflation is likely to erode tax revenues and restrain government growth if government revenue collections are not adjusted fast enough to account for the effects of inflation, or if there is a delay in revenue collections in nominal terms.

6. Other control variables. In order to establish the robustness of our result, we further control other macro variables such as per capita growth rate of GDP; per capita GDP in constant terms; urbanization, measured by urban population as a share of total population; and openness, measured by total imports and exports as percentage of GDP. These variables are quite conventional in existing studies on government size. 
Table 1

Countries included in the study

\begin{tabular}{llll}
\hline Argentina & Colombia & Ireland & South Africa \\
Australia & Denmark & Israel & Spain \\
Austria & France & Luxembourg & Sweden \\
Belgium & Germany & Malaysia & Switzerland \\
Bolivia & Iceland & Mexico & Thailand \\
Brazil & India & Netherlands & United Kingdom \\
Canada & Indonesia & Norway & United States \\
Chile & Iran & Paraguay & Zimbabwe \\
\hline
\end{tabular}

\subsection{Data}

All countries included in the current study have data for at least two levels of government in the International Monetary Fund's (IMF) Government Financial Statistics (GFS) [22]. Based on the availability of data, primarily at the subnational level, we end up with 17 industrial and 15 developing countries over 15 years from 1980-1994 (Table 1).

\subsubsection{Dependent variables}

The three dependent variables analyzed are subnational, national, and aggregate government size, all measured by the ratio of total expenditure at corresponding government level to GDP. In the case of aggregate government size, national and subnational government expenditures are combined. All the data come from the IMF's GFS.

Table 2A provides some descriptive statistics on government sizes for each country from 1980 to 1994 . On average, public sectors at subnational, national, and aggregate levels are substantially larger for the industrial countries $(17,37$, and $54 \%$, respectively) than the ones for developing countries $(6,24$, and $29 \%$, respectively). Moreover, subnational government size varies more significantly in industrial countries than that in developing countries as indicated by the standard deviation (1.6 versus 1.3). The descriptive statistics of each country show that in the industrial-country group, subnational government size varies from 7\% of GDP in Belgium to 32\% in Denmark, whereas the same variable for developing countries ranges from 0.4\% of GDP in Paraguay to 14\% in Brazil. In addition, national and aggregate government sizes are more widely dispersed in developing countries than the ones in industrial countries (with a standard deviation of 4.4 versus 2.5 for national government size, and 5.7 versus 4.2 for aggregate government size). Over the same time period, the average national government size in the developing-country group ranges from 10\% of GDP in South Africa to $60 \%$ in Israel, and aggregate government size ranges from $11 \%$ of GDP in Paraguay to 66\% in Israel. For industrial countries, the average national government size ranges from $22 \%$ of GDP in Switzerland to $45 \%$ in Ireland, 
Table 2A

Descriptive statistics of government sizes for each country (1980-1994)

\begin{tabular}{|c|c|c|c|c|c|c|c|c|c|c|c|c|}
\hline \multirow[t]{2}{*}{ Country } & \multicolumn{4}{|c|}{ Subnational govt. size } & \multicolumn{4}{|c|}{ National govt. size } & \multicolumn{4}{|c|}{ Total govt. size } \\
\hline & Mean & Min & Max & SD & Mean & Min & Max & SD & Mean & Min & Max & SD \\
\hline $\begin{array}{c}\text { Developing } \\
\text { countries }\end{array}$ & 6.0 & 4.2 & 8.4 & 1.3 & 23.9 & 17.6 & 31.4 & 4.4 & 29.0 & 20.2 & 38.9 & 5.7 \\
\hline Argentina & 8.4 & 5.0 & 10.4 & 1.7 & 13.6 & 9.4 & 18.2 & 2.5 & 22.0 & 17.7 & 25.0 & 2.7 \\
\hline Bolivia & 4.2 & 1.5 & 9.4 & 2.1 & 18.1 & 12.4 & 24.0 & 4.2 & 20.8 & 1.5 & 32.0 & 8.3 \\
\hline Brazil & 13.9 & 9.4 & 19.4 & 3.7 & 27.1 & 20.2 & 37.2 & 6.0 & 41.0 & 29.8 & 56.7 & 9.3 \\
\hline Chile & 2.2 & 1.1 & 3.4 & 0.6 & 26.2 & 19.9 & 34.1 & 5.0 & 27.0 & 20.4 & 37.6 & 5.7 \\
\hline Colombia & 5.9 & 5.2 & 6.6 & 0.4 & 14.5 & 13.4 & 16.0 & 1.0 & 16.9 & 11.5 & 21.7 & 3.8 \\
\hline India & 13.3 & 11.8 & 14.3 & 0.8 & 16.0 & 13.0 & 17.9 & 1.7 & 28.6 & 15.8 & 32.2 & 4.0 \\
\hline Indonesia & 2.5 & 2.0 & 3.1 & 0.3 & 20.1 & 16.5 & 24.4 & 2.5 & 21.3 & 14.6 & 27.4 & 3.9 \\
\hline Iran & 1.0 & 0.8 & 1.3 & 0.2 & 25.8 & 17.7 & 35.7 & 6.5 & 24.9 & 18.6 & 37.0 & 5.8 \\
\hline Israel & 7.2 & 5.5 & 8.6 & 0.7 & 60.2 & 37.7 & 89.1 & 16.0 & 66.3 & 43.2 & 97.7 & 16.5 \\
\hline Malaysia & 6.8 & 4.8 & 8.3 & 1.2 & 29.1 & 21.9 & 38.4 & 4.4 & 35.9 & 26.7 & 46.7 & 5.4 \\
\hline Mexico & 4.7 & 3.7 & 6.6 & 0.9 & 20.0 & 14.4 & 30.3 & 5.3 & 24.8 & 19.3 & 34.0 & 4.8 \\
\hline Paraguay & 0.4 & 0.2 & 0.6 & 0.2 & 10.2 & 8.1 & 13.5 & 1.8 & 10.7 & 8.6 & 13.8 & 1.6 \\
\hline South Africa & 10.4 & 7.0 & 19.9 & 4.1 & 30.8 & 22.1 & 38.0 & 4.1 & 41.3 & 31.4 & 54.6 & 6.5 \\
\hline Thailand & 1.5 & 1.1 & 3.5 & 0.5 & 17.2 & 14.1 & 20.5 & 2.2 & 18.7 & 15.2 & 22.3 & 2.5 \\
\hline Zimbabwe & 7.0 & 4.3 & 11.0 & 2.0 & 28.7 & 23.5 & 33.8 & 2.6 & 35.0 & 29.0 & 44.8 & 4.4 \\
\hline $\begin{array}{l}\text { Industrial } \\
\text { countries }\end{array}$ & 17.4 & 14.8 & 19.9 & 1.6 & 37.0 & 32.9 & 40.8 & 2.5 & 54.1 & 46.5 & 60.0 & 4.2 \\
\hline Australia & 17.7 & 15.5 & 19.7 & 1.3 & 25.3 & 22.7 & 27.1 & 1.5 & 43.0 & 38.1 & 46.3 & 2.6 \\
\hline Austria & 17.2 & 16.4 & 18.8 & 0.9 & 39.3 & 36.6 & 42.0 & 1.5 & 56.6 & 53.1 & 60.8 & 2.3 \\
\hline Belgium & 6.9 & 5.9 & 8.4 & 0.9 & 51.4 & 48.2 & 56.0 & 3.0 & 58.3 & 54.2 & 63.9 & 3.8 \\
\hline Canada & 31.3 & 23.7 & 35.5 & 2.8 & 23.7 & 21.1 & 25.3 & 1.3 & 55.0 & 47.9 & 60.8 & 3.6 \\
\hline Denmark & 32.2 & 29.7 & 34.9 & 1.4 & 40.4 & 37.3 & 43.0 & 1.9 & 72.5 & 67.1 & 76.8 & 2.9 \\
\hline France & 10.5 & 7.8 & 16.7 & 3.0 & 44.1 & 39.5 & 47.2 & 2.0 & 54.5 & 47.3 & 60.9 & 3.9 \\
\hline Germany & 22.9 & 19.2 & 24.5 & 1.9 & 33.0 & 30.2 & 33.9 & 1.4 & 56.0 & 49.4 & 58.1 & 3.3 \\
\hline Iceland & 9.0 & 7.9 & 10.4 & 0.8 & 29.7 & 24.8 & 34.4 & 3.4 & 37.5 & 32.2 & 44.3 & 4.3 \\
\hline Ireland & 14.4 & 11.8 & 16.9 & 1.9 & 45.1 & 38.1 & 51.4 & 4.9 & 59.5 & 50.7 & 67.7 & 6.7 \\
\hline Luxemburg & 7.5 & 6.1 & 9.0 & 0.9 & 42.6 & 39.1 & 46.5 & 2.2 & 49.3 & 36.4 & 54.4 & 4.1 \\
\hline Netherlands & 17.7 & 15.6 & 20.3 & 1.5 & 53.9 & 48.0 & 57.7 & 2.7 & 71.6 & 64.0 & 78.0 & 4.0 \\
\hline Norway & 18.5 & 16.7 & 20.7 & 1.3 & 38.0 & 33.7 & 43.2 & 3.2 & 56.6 & 50.4 & 63.2 & 4.4 \\
\hline Spain & 10.9 & 3.3 & 16.5 & 4.5 & 33.2 & 26.5 & 39.4 & 3.6 & 44.1 & 29.8 & 55.9 & 8.0 \\
\hline Sweden & 25.0 & 22.9 & 26.9 & 1.4 & 43.9 & 39.3 & 51.7 & 3.6 & 68.9 & 62.8 & 77.2 & 3.8 \\
\hline Switzerland & 23.1 & 21.3 & 24.9 & 1.5 & 22.5 & 18.4 & 26.6 & 3.5 & 42.1 & 22.4 & 51.5 & 9.5 \\
\hline United Kingdom & 12.8 & 12.2 & 13.7 & 0.5 & 39.4 & 33.9 & 43.2 & 2.6 & 52.2 & 46.2 & 56.3 & 2.8 \\
\hline United States & 18.2 & 16.5 & 20.2 & 1.4 & 23.4 & 22.0 & 25.0 & 0.9 & 41.6 & 38.8 & 44.6 & 1.6 \\
\hline
\end{tabular}

and aggregate government size ranges from $36 \%$ of GDP in Iceland to $73 \%$ in Denmark.

The time path of the dependent variables is shown in Table 2B. For the whole sample, the average subnational government size increased from $11.3 \%$ of GDP in 1980 to $14.5 \%$ in 1994; the average national government size fluctuated around $32 \%$ of GDP; and the total government size rose from $41.3 \%$ of GDP in 1980 to $44.8 \%$ in 1983, and it then declined to $39.8 \%$ of GDP and rose again to a high level of $45.2 \%$ in 1994 . The three government sizes for the developing-country group are relatively rather stable, whereas the corresponding ones for the industrialcountry group have shown a rising trend. Specifically, for the industrial-country group, subnational government size rose from 16.3\% of GDP in 1980 to more than $18 \%$ in the 1990s; national government size and total government size increased quickly in the early 1980s and fluctuated around 38\% of GDP and 55\% of GDP, respectively, from 1983 to 1994. 
Table 2B

The time path of average government sizes by country group

\begin{tabular}{lrrrrrrrrrrrrrrrrrr}
\hline Years & 1980 & 1981 & 1982 & 1983 & 1984 & 1985 & 1986 & 1987 & 1988 & 1989 & 1990 & 1991 & 1992 & 1993 & 1994 \\
\hline $\begin{array}{l}\text { All countries } \\
\text { Subnational govt. size }\end{array}$ & 11.3 & 11.9 & 12.4 & 12.4 & 11.8 & 11.0 & 11.0 & 11.3 & 11.1 & 11.4 & 12.4 & 13.0 & 13.4 & 13.7 & 14.5 \\
National govt. size & 30.1 & 32.0 & 33.3 & 33.6 & 32.2 & 32.4 & 31.7 & 31.6 & 30.5 & 29.8 & 30.9 & 30.3 & 31.8 & 32.6 & 33.1 \\
Total govt. size & 41.3 & 42.7 & 44.6 & 44.8 & 44.1 & 42.3 & 42.6 & 42.0 & 40.7 & 39.5 & 39.8 & 40.9 & 43.1 & 44.1 & 45.2 \\
& & & & & & & & & & & & & & & & \\
$\begin{array}{l}\text { Developing countries } \\
\text { Subnational govt. size }\end{array}$ & 5.5 & 6.0 & 6.1 & 6.2 & 5.9 & 5.7 & 5.7 & 6.0 & 5.7 & 5.7 & 6.6 & 6.4 & 6.5 & 6.9 & 8.8 \\
National govt. size & 24.8 & 26.9 & 28.0 & 28.0 & 26.2 & 25.6 & 24.9 & 24.7 & 23.3 & 22.7 & 23.2 & 21.1 & 22.8 & 23.6 & 24.2 \\
Total govt. size & 30.3 & 31.3 & 32.6 & 32.5 & 32.1 & 29.7 & 30.6 & 29.6 & 28.0 & 27.0 & 27.3 & 25.5 & 27.9 & 28.9 & 30.9 \\
$\begin{array}{l}\text { Industrial countries } \\
\text { Subnational govt. size }\end{array}$ & 16.3 & 16.6 & 17.5 & 17.4 & 17.0 & 16.3 & 16.3 & 16.3 & 16.2 & 16.6 & 16.8 & 17.7 & 18.4 & 18.5 & 18.1 \\
National govt. size & 34.7 & 36.1 & 37.5 & 38.2 & 37.5 & 38.7 & 38.4 & 38.1 & 37.3 & 36.4 & 37.1 & 36.8 & 38.1 & 39.0 & 38.6 \\
Total govt. size & 51.0 & 52.7 & 55.1 & 55.5 & 54.5 & 55.0 & 54.7 & 54.3 & 53.5 & 52.0 & 51.6 & 54.5 & 56.5 & 57.5 & 55.3 \\
\hline
\end{tabular}

\subsubsection{Fiscal decentralization variables}

As indicated earlier, three different variables are used to proxy the level of fiscal decentralization: expenditure decentralization (measured as the ratio of subnational to total government expenditure), revenue decentralization (measured as the ratio of subnational own source revenue to total government revenue), and vertical imbalance (measured as the percentage of expenditures at the subnational level financed by central transfers). Table $3 \mathrm{~A}$ summarizes the descriptive statistics of these fiscal decentralization measures for each country averaged over the period of 1980 to 1994 . Generally, expenditures are 5\% more decentralized than revenues for developing and industrial countries alike as shown by the mean values. In addition, industrial countries are more decentralized than developing countries in both expenditures and revenues (32 and 27\% for industrial countries versus 20 and $15 \%$ for developing countries). Vertical imbalance is larger in the industrial countries (41\%) than in developing countries (35\%). It is also more widely dispersed in developing countries (with an average standard deviation of $11 \%$ ) than in industrial countries (with an average standard deviation of 6\%).

Table 3B presents the time path of the three decentralization measures by country groups. For the whole sample of 32 countries, both expenditures and revenues were increasingly decentralized from 25 and $20 \%$, respectively, in the mid-1980s to around 29 and $25 \%$ in 1994 . Vertical imbalance presented a declining trend from around $40 \%$ in the early 1980 s to around $35 \%$ in the early 1990s.

If we look at developing- and industrial-country groups separately, the most salient feature for the developing-country group is that vertical imbalance substantially and consistently decreased from $45 \%$ in 1982 to $29 \%$ in $1994-$ a reduction of $16 \%$. Revenue decentralization had stabilized at around $14 \%$ until 1985 before it continuously increased to $20 \%$ in 1994, while expenditure decentralization fluctuated widely between 20 and $31 \%$.

For industrial countries, vertical imbalance decreased from $40 \%$ in the 1981 to $36 \%$ in 1989 and then increased to $43 \%$ in 1992 before it dropped back to $39 \%$ in 
Table 3A

Descriptive statistics of fiscal decentralization measures for each country (1980-1994)

\begin{tabular}{|c|c|c|c|c|c|c|c|c|c|c|c|c|}
\hline \multirow[t]{2}{*}{ Country } & \multicolumn{4}{|c|}{ Expenditure decentralization } & \multicolumn{4}{|c|}{ Revenue decentralization } & \multicolumn{4}{|c|}{ Vertical imbalance } \\
\hline & Mean & Min & Max & SD & Mean & Min & Max & SD & Mean & Min & Max & SD \\
\hline $\begin{array}{c}\text { Developing } \\
\text { countries }\end{array}$ & 19.7 & 15.2 & 25.0 & 3.0 & 15.0 & 11.1 & 18.3 & 2.3 & 34.9 & 19.6 & 54.3 & 10.7 \\
\hline Argentina & 38.3 & 22.2 & 46.8 & 7.1 & 32.7 & 16.5 & 42.4 & 9.1 & 28.3 & 0.0 & 62.5 & 19.1 \\
\hline Bolivia & 19.3 & 14.8 & 29.4 & 3.8 & 18.6 & 13.7 & 23.0 & 3.0 & 14.4 & -14.8 & 52.4 & 17.4 \\
\hline Brazil & 33.7 & 28.7 & 42.4 & 3.4 & 24.9 & 18.6 & 30.0 & 3.8 & 36.3 & 25.0 & 42.9 & 5.4 \\
\hline Chile & 7.6 & 3.7 & 9.8 & 1.4 & 5.8 & 2.5 & 7.1 & 1.2 & 23.0 & 1.2 & 49.4 & 15.8 \\
\hline Colombia & 29.0 & 26.3 & 32.1 & 1.9 & 19.1 & 15.7 & 21.4 & 1.8 & 53.3 & 47.5 & 58.6 & 3.6 \\
\hline India & 45.5 & 43.1 & 47.6 & 1.4 & 33.2 & 31.2 & 35.8 & 1.3 & 50.1 & 47.1 & 52.6 & 1.7 \\
\hline Indonesia & 11.2 & 9.6 & 12.6 & 1.0 & 2.8 & 2.2 & 3.7 & 0.4 & 77.5 & 70.3 & 82.7 & 3.6 \\
\hline Iran & 3.8 & 2.6 & 4.9 & 0.9 & 4.7 & 2.4 & 6.7 & 1.6 & 16.4 & 4.8 & 31.2 & 8.1 \\
\hline Israel & 11.2 & 8.1 & 14.3 & 2.2 & 7.2 & 3.6 & 9.7 & 2.5 & 51.4 & 35.7 & 73.6 & 13.6 \\
\hline Malaysia & 18.9 & 17.0 & 21.5 & 1.5 & 16.1 & 13.0 & 20.9 & 1.9 & 21.7 & 0.2 & 43.6 & 15.7 \\
\hline Mexico & 20.1 & 11.0 & 30.5 & 6.2 & 20.4 & 17.8 & 22.9 & 1.5 & 15.5 & -2.9 & 32.5 & 11.8 \\
\hline Paraguay & 3.8 & 1.8 & 5.9 & 1.7 & 3.0 & 1.1 & 5.1 & 1.5 & 17.8 & 6.8 & 34.6 & 7.9 \\
\hline South Africa & 24.9 & 18.4 & 36.6 & 6.3 & 14.0 & 10.3 & 17.1 & 2.1 & 55.9 & 46.3 & 79.2 & 9.9 \\
\hline Thailand & 8.1 & 7.0 & 15.8 & 2.1 & 5.5 & 4.7 & 6.2 & 0.4 & 32.6 & 14.7 & 76.5 & 15.6 \\
\hline Zimbabwe & 19.4 & 13.5 & 24.5 & 3.6 & 17.0 & 12.9 & 22.3 & 2.6 & 29.1 & 12.0 & 42.0 & 10.7 \\
\hline $\begin{array}{l}\text { Industrial } \\
\quad \text { countries }\end{array}$ & 32.0 & 28.9 & 34.8 & 1.9 & 27.3 & 24.6 & 29.5 & 1.6 & 41.0 & 31.6 & 50.7 & 6.3 \\
\hline Australia & 41.2 & 39.4 & 43.5 & 1.3 & 28.2 & 23.8 & 33.7 & 3.6 & 46.6 & 35.3 & 54.7 & 6.4 \\
\hline Austria & 30.4 & 29.5 & 31.4 & 0.6 & 27.1 & 26.3 & 28.6 & 0.8 & 24.0 & 17.3 & 28.2 & 3.2 \\
\hline Belgiu & 11.8 & 10.7 & 14.1 & 1.0 & 62.0 & 60.6 & 63.1 & 0.8 & 60.2 & 50.9 & 71.9 & 6.3 \\
\hline Canada & 56.8 & 49.4 & 58.3 & 2.2 & 51.5 & 45.3 & 53.1 & 1.9 & 31.8 & 28.2 & 36.3 & 2.5 \\
\hline Denmark & 44.4 & 42.6 & 47.5 & 1.2 & 31.2 & 28.8 & 32.2 & 1.0 & 45.7 & 42.3 & 52.3 & 3.5 \\
\hline France & 19.0 & 16.2 & 27.5 & 4.0 & 11.9 & 9.6 & 13.6 & 1.4 & 43.7 & 33.4 & 73.3 & 13.5 \\
\hline Germany & 41.4 & 38.9 & 43.6 & 1.0 & 35.1 & 33.5 & 36.7 & 1.0 & 26.8 & 21.2 & 32.8 & 3.7 \\
\hline Icelan & 23.3 & 21.1 & 27.0 & 1.8 & 22.9 & 21.2 & 25.2 & 1.3 & 8.5 & -0.7 & 19.9 & 5.2 \\
\hline Irelan & 24.2 & 21.6 & 26.5 & 1.1 & 8.8 & 7.9 & 9. & 0.5 & 74.3 & 67.6 & 79.8 & 3.8 \\
\hline Luxemburg & 15.0 & 12.5 & 16.9 & 1.5 & 8.7 & 6.5 & 10.7 & 1.4 & 42.5 & 34.0 & 60.9 & 8.9 \\
\hline Netherlands & 24.7 & 23.3 & 26.0 & 0.9 & 7.7 & 5.7 & 11.0 & 1.6 & 76.4 & 64.9 & 83.3 & 6.0 \\
\hline Norwa & 32.8 & 31.5 & 34.5 & 0.8 & 21.6 & 20.1 & 22.9 & 0.9 & 39.4 & 37.3 & 41.1 & 1.3 \\
\hline Spain & 23.6 & 11.0 & 31.1 & 6.5 & 14.7 & 11.1 & 17.4 & 1.7 & 47.1 & 7.9 & 64.9 & 19.2 \\
\hline Sweden & 36.3 & 31.7 & 40.1 & 2.2 & 32.9 & 29.6 & 35.8 & 2.1 & 21.4 & 13.1 & 26.2 & 3.9 \\
\hline Switzerland & 51.0 & 48.3 & 50.3 & 2.2 & 45.6 & 43.8 & 47.3 & 1.5 & 25.8 & 20.4 & 31.3 & 3.7 \\
\hline United Kingdom & 24.6 & 22.7 & 26.5 & 1.2 & 13.3 & 8.0 & 16.8 & 3.5 & 56.2 & 41.6 & 74.5 & 12.6 \\
\hline United States & 43.8 & 40.8 & 47.3 & 2.1 & 40.4 & 35.6 & 43.1 & 2.1 & 26.1 & 22.7 & 30.6 & 2.5 \\
\hline
\end{tabular}

Table 3B

The time path of average decentralization measures by country group

\begin{tabular}{|c|c|c|c|c|c|c|c|c|c|c|c|c|c|c|c|}
\hline Years & 1980 & 1981 & 1982 & 1983 & 1984 & 1985 & 1986 & 1987 & 1988 & 1989 & 1990 & 1991 & 1992 & 1993 & 1994 \\
\hline All countries & & & & & & & & & & & & & & & \\
\hline $\begin{array}{l}\text { Expenditure } \\
\text { decentralization }\end{array}$ & 26.7 & 27.8 & 26.9 & 25.7 & 26.7 & 25.0 & 25.2 & 24.5 & 24.8 & 26.1 & 26.4 & 27.9 & 27.6 & 26.8 & 28.5 \\
\hline Revenue decentralization & 21.1 & 21.7 & 21.6 & 21.8 & 21.4 & 19.7 & 20.0 & 20.2 & 21.3 & 22.0 & 21.9 & 23.1 & 23.0 & 23.3 & 24.8 \\
\hline Vertical imbalance & 38.0 & 41.2 & 41.7 & 41.0 & 38.3 & 37.6 & 36.3 & 35.3 & 34.9 & 32.7 & 34.8 & 34.9 & 36.8 & 35.3 & 35.3 \\
\hline \multicolumn{16}{|l|}{ Developing countries } \\
\hline $\begin{array}{l}\text { Expenditure } \\
\text { decentralization }\end{array}$ & 19.7 & 30.7 & 26.6 & 21.9 & 27.0 & 26.5 & 27.1 & 23.6 & 23.1 & 29.0 & 20.9 & 25.7 & 28.4 & 30.8 & 26.3 \\
\hline Reve & 14.0 & 15.0 & 14.5 & 14.6 & 14.3 & 13.2 & 13.8 & 13.8 & 15.9 & 15.8 & 16.2 & 17.1 & 16.4 & 17.0 & 20.0 \\
\hline Vertical imbalance & 39.4 & 42.6 & 44.7 & 44.3 & 40.0 & 38.1 & 35.1 & 32.8 & 32.2 & 29.1 & 32.3 & 30.9 & 30.1 & 28.9 & 28.7 \\
\hline \multicolumn{16}{|l|}{ Indus } \\
\hline Expenditure & 32.4 & 25.0 & 27.1 & 29.0 & 26.4 & 23.6 & 23.5 & 25.3 & 26.2 & 22.6 & 30.6 & 29.5 & 26.8 & 22.6 & 30.4 \\
\hline Rev & 27.0 & 26.8 & 27.1 & 27.2 & 27.2 & 25.8 & 25.8 & 25.9 & 26.0 & 27.4 & 26.2 & 27.4 & 27.6 & 27.8 & 27.8 \\
\hline Vertical imbalance & 36.8 & 40.1 & 39.3 & 38.5 & 36.9 & 37.0 & 37.3 & 37.5 & 37.3 & 35.7 & 36.6 & 37.8 & 41.8 & 39.9 & 39.4 \\
\hline
\end{tabular}


1994. Revenue decentralization stabilized between 26 and $28 \%$ while expenditure decentralization fluctuated between 23 and $32 \%$.

It is interesting to observe that for both developing and industrial countries, expenditure decentralization tends to fluctuate dramatically-between 20 and $31 \%$ for developing countries and between 23 and $32 \%$ for industrial countriesin comparison with the relatively stable levels of revenue decentralization, which stayed around 14\% until 1987 before gradually increasing to $20 \%$ in 1994 for developing countries and staying between 26 to $28 \%$ for industrial countries. This pattern indicates that expenditures can be easily altered (in the legal or operational sense) with the change in fiscal policies and economic environments.

\subsubsection{Political/institutional variables}

Four variables are used to measure the influence of political/institutional factors on government size at one or more levels. The first variable measures the lack of independence of the central bank (called political central bank). A dummy variable equals one if the central bank governor changes within 6 months of a political transition and zero otherwise. The source of this information is Cukierman and Webb [23] and the Europa World Yearbook [24].

The two additional variables are dummies to measure the possible effects of the political environment on central and/or subnational public finance: (1) Unitary state versus federal state. A dummy variable equals one if the country is a federation and zero otherwise. (2) Elected versus non-elected subnational governments. A dummy variable equals one if the subnational government is elected and zero otherwise. The source of this information is primarily the Europa World Yearbook [24], with additional information from the country reports by The Economist Intelligence Unit [25].

Other researchers have found that constraints on subnational borrowing could help improve fiscal performance of subnational governments and restrain the overall size of government (Ter-Minassian and Craig [26] and IDB [27]). The dummy variable designed to capture this effect equals one if the country has any form of prohibition against borrowing by subnational government or a nondiscretionary rule to constraint it ex ante, which are the two types of constraints Ter-Minassian and Craig [26] considered, and zero otherwise.

\subsubsection{Control variables}

To ensure that any correlation between fiscal decentralization and government sizes is not due to the effect of the general macroeconomic environment, five control variables are included in the analysis: (1) the growth rate of real per capita GDP, (2) real GDP per capita, (3) changes in the consumer price index (CPI) with a one-year lag, (4) openness, measured by the sum of imports and exports as a percentage in GDP, and (5) the percentage of urban population. Sources of these variables are the International Financial Statistics (IFS) of the IMF [22] and the World Development Indicators (WDI) of the World Bank [28]. 


\subsection{Methodology}

To investigate the relationship between the size of government and fiscal decentralization and other political and economic variables, the following model is adopted:

$$
\text { GovtSize }_{i, t}=\alpha_{i}+\alpha_{1} \mathrm{FD}_{i, t}+\alpha_{2} \text { Political }_{i, t}+\alpha_{3} \text { Control }_{i, t}+\varepsilon_{i, t},
$$

where GovtSize $i, t$ represents the three different measures of government size, i.e., GovtSize ${ }_{i, t}$ is the aggregate government size, or national government size, or subnational government size; $\alpha_{i}$ is the country fixed effects; $\mathrm{FD}_{i, t}$ represents the three different measures of fiscal decentralization, i.e., $\mathrm{FD}_{i, t}$ is the expenditure decentralization, or revenue decentralization, or vertical imbalance. When measuring fiscal decentralization using vertical imbalance, an interaction term between vertical imbalance and borrowing constraints is added to capture at least part of the effect of having hard/soft budget constraints at the subnational level (see Stein [8]). Political ${ }_{i, t}$ represents the four political/institutional variables, i.e., the presence of borrowing constraints, subnational government elected, federal versus unitary states, and political central bank. Control $i_{i, t}$ is the other five control variables in our regression analysis.

First, all coefficients are estimated using the fixed-effects approach. Second, since the fixed-effects approach has the disadvantage of dropping the variables that may reflect important economic and, in particular, institutional aspects of the model, the feasible generalized least squares (FGLS) method is also adopted with the corrections for panel heteroskedasticity and panel serial correlation. This approach is used because in many cross-section data sets the variance for each of the panels differs. Moreover, the correlation parameter of serial correlation may also be unique for each panel.

\section{Results}

Tables $4 \mathrm{~A}, 5 \mathrm{~A}$, and $6 \mathrm{~A}$ present the regression results on how fiscal decentralization affects subnational, national, and aggregate government size using the fixed-effects approach, and Tables 4B, 5B, and 6B report the corresponding FGLS results. As we mentioned earlier, it is obvious that decentralization should increase the size of subnational governments while shrinking the size of the national government. This almost tautological point is fully supported in our regression analyses (using both the fixed-effects approach and FGLS).

\subsection{Subnational government size}

Table 4A shows the fixed-effects estimations on the relationship between fiscal decentralization and subnational government size. Expenditure decentralization, 
Table 4A

Decentralization and subnational government size (fixed effects)

\begin{tabular}{|c|c|c|c|}
\hline \multirow[t]{2}{*}{ Explanatory variable } & \multicolumn{3}{|c|}{ Dependent variable: subnational government size } \\
\hline & Coefficients & Coefficients & Coefficients \\
\hline Expenditure decentralization & $\begin{array}{l}0.363^{c} \\
(15.911)\end{array}$ & & \\
\hline Revenue decentralization & & $\begin{array}{l}0.122^{\mathrm{c}} \\
(3.417)\end{array}$ & \\
\hline Vertical imbalance & & & $\begin{array}{l}0.046^{\mathrm{b}} \\
(2.469)\end{array}$ \\
\hline Vertical imbalance $*$ borrowing constraints & & & $\begin{array}{l}0.063^{\mathrm{c}} \\
(3.090)\end{array}$ \\
\hline Real GDP per capita (USD) & $\begin{array}{l}-5.75 \times 10^{-5} \\
(-1.249)\end{array}$ & $\begin{array}{l}-7.29 \times 10^{-5} \\
(-1.194)\end{array}$ & $\begin{array}{l}-3.9 \times 10^{-5} \\
(-0.804)\end{array}$ \\
\hline Real GDP growth rate & $\begin{array}{l}-0.063^{c} \\
(-3.307)\end{array}$ & $\begin{array}{l}-0.059^{\mathrm{b}} \\
(-2.304)\end{array}$ & $\begin{array}{l}-0.032 \\
(-1.569)\end{array}$ \\
\hline Presence of borrowing constraints & dropped & dropped & dropped \\
\hline Subnational govt. elected & $\begin{array}{l}-1.228^{a} \\
(-1.993)\end{array}$ & $\begin{array}{l}0.678 \\
(0.909)\end{array}$ & $\begin{array}{l}-1.783^{b} \\
(-2.843)\end{array}$ \\
\hline Federal vs. unitary state & dropped & dropped & dropped \\
\hline Political Central Bank & $\begin{array}{l}1.032^{c} \\
(4.326)\end{array}$ & $\begin{array}{l}0.416 \\
(1.455)\end{array}$ & $\begin{array}{l}0.681^{b} \\
(2.691)\end{array}$ \\
\hline Urban population & $\begin{array}{l}0.111^{\mathrm{b}} \\
(2.158)\end{array}$ & $\begin{array}{l}0.112 \\
(1.627)\end{array}$ & $\begin{array}{l}0.286^{\mathrm{c}} \\
(5.133)\end{array}$ \\
\hline Openness & $\begin{array}{l}-0.005 \\
(-0.554)\end{array}$ & $\begin{array}{l}-0.012 \\
(-0.963)\end{array}$ & $\begin{array}{l}-0.007 \\
(-0.630)\end{array}$ \\
\hline Lag CPI inflation & $\begin{array}{l}0.000 \\
(-0.840)\end{array}$ & $\begin{array}{l}0.000 \\
(0.593)\end{array}$ & $\begin{array}{l}0.000 \\
(2.399)\end{array}$ \\
\hline Constant & $\begin{array}{l}-3.037 \\
(-0.991)\end{array}$ & $\begin{array}{l}3.012 \\
(0.751)\end{array}$ & $\begin{array}{l}-9.080^{\mathrm{b}} \\
(-2.710)\end{array}$ \\
\hline Number of observations & 345 & 346 & 347 \\
\hline Number of groups & 32 & 32 & 32 \\
\hline$R^{2}$ within & 0.4883 & 0.1003 & 0.4171 \\
\hline$R^{2}$ between & 0.6802 & 0.2277 & 0.068 \\
\hline$R^{2}$ overall & 0.6667 & 0.2142 & 0.0854 \\
\hline
\end{tabular}

The number in parentheses represents the $t$-statistic associated with each coefficient.

a Indicates a significance level at $10 \%$.

b Indicates a significance level at $5 \%$.

c Indicates a significance at $1 \%$.

revenue decentralization, and vertical imbalance are all found to be positively and significantly associated with subnational government size. The FGLS regressions in Table 4B demonstrate very similar results with a close magnitude of estimated coefficients. These findings confirm John Wallis's hypothesis that fiscal decentralization may lead to larger subnational governments because local constituents with more control over public decisions at subnational levels than 
Table 4B

Decentralization and subnational government size (FGLS)

\begin{tabular}{|c|c|c|c|}
\hline \multirow[t]{2}{*}{ Explanatory variable } & \multicolumn{3}{|c|}{ Dependent variable: subnational government size } \\
\hline & Coefficients & Coefficients & Coefficients \\
\hline Expenditure decentralization & $\begin{array}{l}0.316^{\mathrm{c}} \\
(22.025)\end{array}$ & & \\
\hline Revenue decentralization & & $\begin{array}{l}0.172^{\mathrm{c}} \\
(9.062)\end{array}$ & \\
\hline Vertical imbalance & & & $\begin{array}{l}0.065^{\mathrm{c}} \\
(4.012)\end{array}$ \\
\hline Vertical imbalance $*$ borrow constraints & & & $\begin{array}{l}-0.007 \\
(-0.383)\end{array}$ \\
\hline Real GDP per capita (USD) & $\begin{array}{l}3.150 \times 10^{-4 c} \\
(14.857)\end{array}$ & $\begin{array}{l}4.638 \times 10^{-4 c} \\
(10.239)\end{array}$ & $\begin{array}{l}0.001^{\mathrm{c}} \\
(16.260)\end{array}$ \\
\hline Real GDP growth rate & $\begin{array}{l}-0.048^{\mathrm{c}} \\
(-5.866)\end{array}$ & $\begin{array}{l}-0.044^{\mathrm{c}} \\
(-4.578)\end{array}$ & $\begin{array}{l}-0.056^{\mathrm{c}} \\
(-5.314)\end{array}$ \\
\hline Presence of borrowing constraints & $\begin{array}{l}0.004 \\
(0.015)\end{array}$ & $\begin{array}{l}-1.745 \\
(-1.435)\end{array}$ & $\begin{array}{l}0.941 \\
(0.898)\end{array}$ \\
\hline Subnational govt. elected & $\begin{array}{l}-0.419 \\
(-1.467)\end{array}$ & $\begin{array}{l}0.825^{\mathrm{b}} \\
(2.105)\end{array}$ & $\begin{array}{l}1.277^{\mathrm{c}} \\
(3.711)\end{array}$ \\
\hline Federal vs. unitary state & $\begin{array}{l}-1.007^{c} \\
(-2.559)\end{array}$ & $\begin{array}{l}-3.237^{c} \\
(-6.310)\end{array}$ & $\begin{array}{l}-2.787^{\mathrm{c}} \\
(-5.098)\end{array}$ \\
\hline Political Central Bank & $\begin{array}{l}0.385^{\mathrm{c}} \\
(3.729)\end{array}$ & $\begin{array}{l}0.287^{\mathrm{b}} \\
(2.174)\end{array}$ & $\begin{array}{l}0.354^{\mathrm{c}} \\
(2.910)\end{array}$ \\
\hline Urban population & $\begin{array}{l}0.008^{\mathrm{a}} \\
(1.637)\end{array}$ & $\begin{array}{l}-0.044^{\mathrm{c}} \\
(-3.288)\end{array}$ & $\begin{array}{l}-0.035^{\mathrm{c}} \\
(-2.633)\end{array}$ \\
\hline Openness & $\begin{array}{l}0.001 \\
(0.249)\end{array}$ & $\begin{array}{l}-0.003 \\
(-0.604)\end{array}$ & $\begin{array}{l}-0.014^{\mathrm{b}} \\
(-2.217)\end{array}$ \\
\hline Lag CPI inflation & $\begin{array}{l}-1.033 \times 10^{-4} \\
(-1.484)\end{array}$ & $\begin{array}{l}1.630 \times 10^{-5} \\
(0.218)\end{array}$ & $\begin{array}{l}1.190 \times 10^{-4 \mathrm{c}} \\
(3.233)\end{array}$ \\
\hline Constant & $\begin{array}{l}-1.359^{\mathrm{c}} \\
(-3.509)\end{array}$ & $\begin{array}{l}6.449^{c} \\
(4.207)\end{array}$ & $\begin{array}{l}4.00^{\mathrm{c}} \\
(3.172)\end{array}$ \\
\hline Number of observations & 345 & 346 & 347 \\
\hline Number of groups & 31 & 31 & 31 \\
\hline$\chi^{2}$ & 2287 & 533 & 746 \\
\hline Log likelihood & -158 & -236 & -234 \\
\hline$P$ & 0.000 & 0.000 & 0.000 \\
\hline Computed $R^{2}$ & 0.879 & 0.530 & 0.614 \\
\hline
\end{tabular}

The number in parentheses represents the $t$-statistic associated with each coefficient.

a Indicates a significance level at $10 \%$.

$\mathrm{b}$ Indicates a significance level at 5\%.

${ }^{\mathrm{c}}$ Indicates a significance at $1 \%$.

at the national level may empower local governments with a wider range of functions and responsibilities.

In the equations using expenditure decentralization and vertical imbalance variables, we find that elected subnational governments tend to be smaller 
(Table 4A). But when using FGLS estimations with the control of revenue decentralization and vertical imbalance, elected subnational governments tend to expand (Table 4B). These seemingly contradictory, inconclusive findings indicate that political participation may not be a powerful institutional constraint on subnational governments. In particular, political participation could be relatively ineffective in restraining the growth of the public sector at the subnational level when more revenues are at the discretion of local officials.

Table 4B shows that a federal state tends to have a smaller subnational government than a unitary state. This effect is not detected in the fixed-effects estimations because the variable is dropped (see Table 4A). Both Tables 4A and $4 \mathrm{~B}$ indicate that a less independent central bank (political central bank), as predicted, increases subnational government size resulting from less independent monetary policy and perhaps even monetization of fiscal deficits. But the effect of borrowing constraints on subnational government size has not been consistent and/or significant in Table 4B.

Among the other control variables, real GDP growth rate is negatively related to subnational government size. Urban population is positively associated with subnational government size, as is the lagged CPI inflation in the equation using vertical imbalance. But the borrowing constraints/vertical imbalance interaction variable tends to have mixed and even insignificant signs.

\subsection{National government size}

Tables $5 \mathrm{~A}$ and $5 \mathrm{~B}$ show the regression results for the relationship between fiscal decentralization and national government size using the fixed-effects approach and FGLS, respectively. As expected, both expenditure and revenue decentralization lead to a smaller national government. But note that a vertical imbalance, besides its positive effect on subnational government size (Table 4A), increases the size of national government as well. A possible explanation is that intergovernmental transfers in the form of matching grants to subnational governments gives them more incentive to expand spending in order to lure more transfers from the central government. When matching grants increase, national spending itself will also rise proportionally. That is to say, to make lots of grants to subnational governments, the national government must itself be large.

For the two estimation approaches (Tables 5A and 5B), a less independent central bank significantly increases national government size; and a nation with elected subnational governments does not necessarily have a smaller size of the national government. Furthermore, a federal state is likely to reduce the sizes of both national (Table 5B) and subnational governments (Table 4B). Among other control variables, the presence of borrowing constraints tends to have mixed effects on national government size; higher GDP growth rates reduce national government size; and openness is significantly and positively associated with the size of the public sector at the national level. In addition, the interaction variable 
Table 5A

Decentralization and national government size (fixed-effects)

\begin{tabular}{|c|c|c|c|}
\hline \multirow[t]{2}{*}{ Explanatory variable } & \multicolumn{3}{|c|}{ Dependent variable: national government size } \\
\hline & Coefficients & Coefficients & Coefficients \\
\hline Expenditure decentralization & $\begin{array}{l}-0.316^{\mathrm{c}} \\
(-3.844)\end{array}$ & & \\
\hline Revenue decentralization & & $\begin{array}{l}-0.435^{\mathrm{c}} \\
(-4.542)\end{array}$ & \\
\hline Vertical imbalance & & & $\begin{array}{l}0.101^{\mathrm{a}} \\
(1.727)\end{array}$ \\
\hline Vertical imbalance $*$ borrowing constraints & & & $\begin{array}{l}0.108 \\
(1.705)\end{array}$ \\
\hline Real GDP per capita (USD) & $\begin{array}{l}-1.111 \times 10^{-4} \\
(-0.672)\end{array}$ & $\begin{array}{l}-9.333 \times 10^{-5} \\
(-0.569)\end{array}$ & $\begin{array}{l}-3.72 \times 10^{-5} \\
(-0.243)\end{array}$ \\
\hline Real GDP growth rate & $\begin{array}{l}-0.243^{c} \\
(-3.521)\end{array}$ & $\begin{array}{l}-0.240^{\mathrm{c}} \\
(-3.509)\end{array}$ & $\begin{array}{l}-0.201^{\mathrm{c}} \\
(-3.120)\end{array}$ \\
\hline Presence of borrowing constraints & dropped & dropped & dropped \\
\hline Subnational govt. elected & $\begin{array}{l}1.341 \\
(0.605)\end{array}$ & $\begin{array}{l}-0.307 \\
(-0.142)\end{array}$ & $\begin{array}{l}-4.697^{b} \\
(-2.249)\end{array}$ \\
\hline Federal vs. unitary state & dropped & dropped & dropped \\
\hline Political Central Bank & $\begin{array}{l}3.355^{\mathrm{c}} \\
(3.911)\end{array}$ & $\begin{array}{l}4.223^{\mathrm{c}} \\
(4.959)\end{array}$ & $\begin{array}{l}3.8844^{\mathrm{c}} \\
(4.928)\end{array}$ \\
\hline Urban population & $\begin{array}{l}-0.412^{\mathrm{b}} \\
(-2.227)\end{array}$ & $\begin{array}{l}-0.313 \\
(-1.689)\end{array}$ & $\begin{array}{l}-0.180 \\
(-1.038)\end{array}$ \\
\hline Openness & $\begin{array}{l}0.063^{\mathrm{a}} \\
(1.817)\end{array}$ & $\begin{array}{l}0.062^{\mathrm{a}} \\
(1.790)\end{array}$ & $\begin{array}{l}0.089^{\mathrm{b}} \\
(2.742)\end{array}$ \\
\hline Lag CPI inflation & $\begin{array}{l}0.000 \\
(-0.430)\end{array}$ & $\begin{array}{l}0.000 \\
(-0.500)\end{array}$ & $\begin{array}{l}0.000 \\
(-0.161)\end{array}$ \\
\hline Constant & $\begin{array}{l}63.735^{\mathrm{c}} \\
(5.784)\end{array}$ & $\begin{array}{l}58.975^{\mathrm{c}} \\
(5.447)\end{array}$ & $\begin{array}{l}34.134^{\mathrm{c}} \\
(3.252)\end{array}$ \\
\hline Number of observations & 345 & 346 & 347 \\
\hline Number of groups & 32 & 32 & 31 \\
\hline$R^{2}$ within & 0.1603 & 0.1754 & 0.2848 \\
\hline$R^{2}$ between & 0.07 & 0.0469 & 0.004 \\
\hline$R^{2}$ overall & 0.0546 & 0.0357 & 0.009 \\
\hline
\end{tabular}

The number in parentheses represents the $t$-statistic associated with each coefficient.

${ }^{\text {a }}$ Indicates a significance level at $10 \%$.

${ }^{b}$ Indicates a significance level at 5\%.

${ }^{\mathrm{c}}$ Indicates a significance level at $1 \%$.

of borrowing constraints/vertical imbalance has opposite effects on national government size for the two estimation approaches.

\subsection{Aggregate government size}

Tables $6 \mathrm{~A}$ and $6 \mathrm{~B}$ report the regression results on the relationship between fiscal decentralization and aggregate government size using the fixed-effects 
Table 5B

Decentralization and national government size (FGLS)

\begin{tabular}{|c|c|c|c|}
\hline \multirow[t]{2}{*}{ Explanatory variables } & \multicolumn{3}{|c|}{ Dependent variable: national government size } \\
\hline & Coefficients & Coefficients & Coefficients \\
\hline Expenditure decentralization & $\begin{array}{l}-0.313^{\mathrm{c}} \\
(-9.698)\end{array}$ & & \\
\hline Revenue decentralization & & $\begin{array}{l}-0.238^{c} \\
(-6.861)\end{array}$ & \\
\hline Vertical imbalance & & & $\begin{array}{l}0.263^{\mathrm{c}} \\
(9.535)\end{array}$ \\
\hline Vertical imbalance $*$ borrow constraints & & & $\begin{array}{l}-0.138^{\mathrm{c}} \\
(-4.207)\end{array}$ \\
\hline Real GDP per capita (USD) & $\begin{array}{l}2.788 \times 10^{-4 c} \\
(3.248)\end{array}$ & $\begin{array}{l}1.859 \times 10^{-4 b} \\
(2.237)\end{array}$ & $\begin{array}{l}2.830 \times 10^{-5} \\
(0.495)\end{array}$ \\
\hline Real GDP growth rate & $\begin{array}{l}-0.176^{\mathrm{c}} \\
(-6.324)\end{array}$ & $\begin{array}{l}-0.175^{\mathrm{c}} \\
(-5.535)\end{array}$ & $\begin{array}{l}-0.123^{\mathrm{c}} \\
(-3.969)\end{array}$ \\
\hline Presence of borrowing constraints & $\begin{array}{l}-0.721 \\
(-0.420)\end{array}$ & $\begin{array}{l}2.027 \\
(1.172)\end{array}$ & $\begin{array}{l}4.615^{\mathrm{b}} \\
(2.467)\end{array}$ \\
\hline Subnational govt. elected & $\begin{array}{l}0.581 \\
(0.454)\end{array}$ & $\begin{array}{l}0.058 \\
(0.045)\end{array}$ & $\begin{array}{l}-1.712 \\
(-1.591)\end{array}$ \\
\hline Federal vs. unitary state & $\begin{array}{l}-1.751 \\
(-0.855)\end{array}$ & $\begin{array}{l}1.876 \\
(1.177)\end{array}$ & $\begin{array}{l}-2.706^{\mathrm{b}} \\
(-2.494)\end{array}$ \\
\hline Political Central Bank & $\begin{array}{l}1.120^{\mathrm{c}} \\
(2.971)\end{array}$ & $\begin{array}{l}1.640^{\mathrm{c}} \\
(3.606)\end{array}$ & $\begin{array}{l}1.258^{\mathrm{c}} \\
(3.253)\end{array}$ \\
\hline Urban population & $\begin{array}{l}0.202^{\mathrm{c}} \\
(4.930)\end{array}$ & $\begin{array}{l}0.212^{\mathrm{c}} \\
(5.087)\end{array}$ & $\begin{array}{l}0.298^{\mathrm{c}} \\
(9.895)\end{array}$ \\
\hline Openness & $\begin{array}{l}0.038^{\mathrm{b}} \\
(2.332)\end{array}$ & $\begin{array}{l}0.074^{\mathrm{c}} \\
(4.310)\end{array}$ & $\begin{array}{l}0.100^{\mathrm{c}} \\
(7.849)\end{array}$ \\
\hline Lag CPI inflation & $\begin{array}{l}-2.172 \times 10^{-4} \\
(-0.865)\end{array}$ & $\begin{array}{l}-2.592 \times 10^{-4} \\
(-0.936)\end{array}$ & $\begin{array}{l}-1.537 \times 10^{-4} \\
(-0.782)\end{array}$ \\
\hline Constant & $\begin{array}{l}19.392^{\mathrm{c}} \\
(8.670)\end{array}$ & $\begin{array}{l}11.652^{\mathrm{c}} \\
(5.027)\end{array}$ & $\begin{array}{l}-2.980^{\mathrm{a}} \\
(-1.881)\end{array}$ \\
\hline Number of observations & 345 & 345 & 345 \\
\hline Number of groups & 31 & 31 & 31 \\
\hline$\chi^{2}$ & 241 & 180 & 1430 \\
\hline Log likelihood & -518 & -549 & -546 \\
\hline$P$ & 0.000 & 0.000 & 0.000 \\
\hline Computed $R^{2}$ & 0.189 & 0.141 & 0.567 \\
\hline
\end{tabular}

The number in parentheses represents the $t$-statistic associated with each coefficient.

a Indicates a significance level at $10 \%$.

b Indicates a significance level at $5 \%$.

c Indicates a significance level at $1 \%$.

approaches and FGLS, respectively. It is found that aggregate government size is negatively and significantly associated with revenue decentralization with the fixed-effects approach (Table 6A). This is because the rise of subnational revenue 
Table 6A

Decentralization and aggregate government size (fixed-effects)

\begin{tabular}{|c|c|c|c|}
\hline \multirow[t]{2}{*}{ Explanatory variable } & \multicolumn{3}{|c|}{ Dependent variable: aggregate government size } \\
\hline & Coefficients & Coefficients & Coefficients \\
\hline Expenditure decentralization & $\begin{array}{l}0.048 \\
(1.484)\end{array}$ & & \\
\hline Revenue decentralization & & $\begin{array}{l}-0.293^{\mathrm{c}} \\
(-2.519)\end{array}$ & \\
\hline Vertical imbalance & & & $\begin{array}{l}0.134^{\mathrm{b}} \\
(2.019)\end{array}$ \\
\hline $\begin{array}{l}\text { Vertical imbalance } * \text { borrowing } \\
\text { constraints }\end{array}$ & & & $\begin{array}{l}0.185^{\mathrm{b}} \\
(2.588)\end{array}$ \\
\hline Real GDP per capita (USD) & $\begin{array}{l}-1.686 \times 10^{-4} \\
(-0.850)\end{array}$ & $\begin{array}{l}-1.695 \times 10^{-4} \\
(-0.849)\end{array}$ & $\begin{array}{l}-2.058 \times 10^{-4} \\
(-1.208)\end{array}$ \\
\hline Real GDP growth rate & $\begin{array}{l}-0.307^{\mathrm{c}} \\
(-3.704)\end{array}$ & $\begin{array}{l}-0.283^{\mathrm{c}} \\
(-3.397)\end{array}$ & $\begin{array}{l}-0.223^{\mathrm{c}} \\
(-3.037)\end{array}$ \\
\hline Presence of borrowing constraints & dropped & dropped & dropped \\
\hline Subnational govt. elected & $\begin{array}{l}0.113 \\
(0.043)\end{array}$ & $\begin{array}{l}3.646 \\
(1.496)\end{array}$ & $\begin{array}{l}-3.677 \\
(-1.666)\end{array}$ \\
\hline Federal vs. unitary state & dropped & dropped & dropped \\
\hline Political Central Bank & $\begin{array}{l}4.387^{\mathrm{c}} \\
(4.266)\end{array}$ & $\begin{array}{l}4.618^{\mathrm{c}} \\
(4.456)\end{array}$ & $\begin{array}{l}4.441^{\mathrm{c}} \\
(4.990)\end{array}$ \\
\hline Urban population & $\begin{array}{l}-0.301 \\
(-1.358)\end{array}$ & $\begin{array}{l}-0.187 \\
(-0.831)\end{array}$ & $\begin{array}{l}0.126 \\
(0.640)\end{array}$ \\
\hline Openness & $\begin{array}{l}0.058 \\
(1.387)\end{array}$ & $\begin{array}{l}0.048 \\
(1.136)\end{array}$ & $\begin{array}{l}0.079^{\mathrm{b}} \\
(2.161)\end{array}$ \\
\hline Lag CPI inflation & $\begin{array}{l}0.000 \\
(-0.554)\end{array}$ & $\begin{array}{l}0.000 \\
(0.420)\end{array}$ & $\begin{array}{l}0.000 \\
(1.200)\end{array}$ \\
\hline Constant & $\begin{array}{l}60.698^{\mathrm{c}} \\
(4.595)\end{array}$ & $\begin{array}{l}58.411^{\mathrm{c}} \\
(4.449)\end{array}$ & $\begin{array}{l}23.699^{\mathrm{b}} \\
(2.011)\end{array}$ \\
\hline Number of observations & 345 & 346 & 347 \\
\hline Number of groups & 32 & 32 & 32 \\
\hline$R^{2}$ within & 0.1159 & 0.1286 & 0.3737 \\
\hline$R^{2}$ between & 0.2883 & 0.2072 & 0.0605 \\
\hline$R^{2}$ overall & 0.2324 & 0.1539 & 0.0974 \\
\hline
\end{tabular}

The number in parentheses represents the $t$-statistic associated with each coefficient.

a Indicates a significance level at $10 \%$.

${ }^{\mathrm{b}}$ Indicates a significance level at $5 \%$.

${ }^{\mathrm{c}}$ Indicates a significance level at $1 \%$.

share in total revenues reduces national government size (Table 5A) by more than it increases subnational government size (Table 4A).

Like Oates's [14] empirical results based on cross-section, cross-country regressions, we also find a positive association between expenditure decentralization and aggregate government size for both approaches. Whereas the estimated coefficient for FGLS is highly significant, the corresponding one from the fixed- 
Table 6B

Decentralization and aggregate government size (FGLS)

\begin{tabular}{|c|c|c|c|}
\hline \multirow[t]{2}{*}{ Explanatory variable } & \multicolumn{3}{|c|}{ Dependent variable: aggregate government size } \\
\hline & Coefficients & Coefficients & Coefficients \\
\hline Expenditure decentralization & $\begin{array}{l}0.119^{c} \\
(2.781)\end{array}$ & & \\
\hline Revenue decentralization & & $\begin{array}{l}-0.015 \\
(-0.237)\end{array}$ & \\
\hline Vertical imbalance & & & $\begin{array}{l}0.265^{\mathrm{c}} \\
(7.545)\end{array}$ \\
\hline Vertical imbalance $*$ borrowing constraints & & & $\begin{array}{l}-0.034 \\
(-0.837)\end{array}$ \\
\hline Real GDP per capita (USD) & $\begin{array}{l}5.00 \times 10^{-4 c} \\
(4.482)\end{array}$ & $\begin{array}{l}0.001^{\mathrm{c}} \\
(6.840)\end{array}$ & $\begin{array}{l}0.001^{\mathrm{c}} \\
(5.874)\end{array}$ \\
\hline Real GDP growth rate & $\begin{array}{l}-0.256^{\mathrm{c}} \\
(-6.790)\end{array}$ & $\begin{array}{l}-0.235^{\mathrm{c}} \\
(-6.056)\end{array}$ & $\begin{array}{l}-0.225^{\mathrm{c}} \\
(-5.819)\end{array}$ \\
\hline Presence of borrowing constraints & $\begin{array}{l}-0.652 \\
(-0.334)\end{array}$ & $\begin{array}{l}-1.305 \\
(-0.600)\end{array}$ & $\begin{array}{l}-0.656 \\
(-0.253)\end{array}$ \\
\hline Subnational govt. elected & $\begin{array}{l}0.703 \\
(0.497)\end{array}$ & $\begin{array}{l}0.570 \\
(0.337)\end{array}$ & $\begin{array}{l}1.820 \\
(1.221)\end{array}$ \\
\hline Federal vs. unitary state & $\begin{array}{l}-6.936^{\mathrm{b}} \\
(-2.020)\end{array}$ & $\begin{array}{l}-4.498 \\
(-1.391)\end{array}$ & $\begin{array}{l}-5.781^{\mathrm{c}} \\
(-3.045)\end{array}$ \\
\hline Political Central Bank & $\begin{array}{l}2.041^{\mathrm{c}} \\
(4.572)\end{array}$ & $\begin{array}{l}1.785^{\mathrm{c}} \\
(3.130)\end{array}$ & $\begin{array}{l}2.095^{\mathrm{c}} \\
(3.817)\end{array}$ \\
\hline Urban population & $\begin{array}{l}0.238^{\mathrm{c}} \\
(5.148)\end{array}$ & $\begin{array}{l}0.152^{\mathrm{c}} \\
(2.924)\end{array}$ & $\begin{array}{l}0.300^{\mathrm{c}} \\
(6.911)\end{array}$ \\
\hline Openness & $\begin{array}{l}0.021 \\
(1.028)\end{array}$ & $\begin{array}{l}0.056^{\mathrm{c}} \\
(2.775)\end{array}$ & $\begin{array}{l}0.058^{c} \\
(2.934)\end{array}$ \\
\hline Lag CPI inflation & $\begin{array}{l}-2.800 \times 10^{-4} \\
(-0.751)\end{array}$ & $\begin{array}{l}-1.33 \times 10^{-4} \\
(-0.231)\end{array}$ & $\begin{array}{l}2.18 \times 10^{-4} \\
(0.428)\end{array}$ \\
\hline Constant & $\begin{array}{l}16.804^{\mathrm{c}} \\
(2.454)\end{array}$ & $\begin{array}{l}19.540^{\mathrm{c}} \\
(6.989)\end{array}$ & $\begin{array}{l}1.595 \\
(0.865)\end{array}$ \\
\hline Number of observations & 345 & 346 & 347 \\
\hline Number of groups & 31 & 31 & 31 \\
\hline$\chi^{2}$ & 388 & 302 & 1266 \\
\hline Log likelihood & -615 & -640 & -649 \\
\hline$P$ & 0.000 & 0.000 & 0.000 \\
\hline Computed $R^{2}$ & 0.240 & 0.191 & 0.494 \\
\hline
\end{tabular}

The number in parentheses represents the $t$-statistic associated with each coefficient.

a Indicates a significance level at $10 \%$.

b Indicates a significance level at $5 \%$.

c Indicates a significance level at $1 \%$.

effects model is not significant. This inconsistency may suggest that given the sample countries and the time span of this regression, expenditure decentralization would increase subnational government size and reduce national government 
size to nearly the same extent and hence affect aggregate government size marginally.

Since vertical imbalance, as demonstrated in Tables $4 \mathrm{~A}$ and $5 \mathrm{~A}$ and is positively associated with both subnational and national government size, it leads to a larger aggregate government size (Tables 6A and 6B). This finding confirms the common belief that vertical imbalance exacerbates the problem of the commons, amplifies the flypaper effect, and consequently encourages the expansion of the public sector at subnational level and forces the national government to grow proportionately. As a result, the greater the share of intergovernmental transfers in subnational public spending, the bigger the aggregate government size. This outcome is fully consistent with the results of Oates [14], Grossman [19], Edhaie [20], Stein [8], and others.

As for other variables, it is found that a less independent central bank (political central bank) increases both subnational and national government sizes significantly, leading to a larger aggregated public sector. A federal state, with a more decentralized regime than a unitary one, has a smaller aggregate public sector (Table 6B). The presence of borrowing constraints, however, shows no significant effect on aggregate government size. The rate of real GDP growth is negatively associated with aggregate government size, whereas inflation has no significant effect. Moreover, both urbanization and openness raise aggregate government size. Finally, the interaction variable of borrowing constraints/vertical imbalance has mixed and even insignificant effects on aggregate government size.

\section{Summary}

This paper is the first attempt to examine the effects of fiscal decentralization on the sizes of the subnational, national, and aggregate governments. Using an econometric analysis of a panel of 32 industrial and developing countries, 1980-1994, we find that expenditure decentralization leads to larger aggregate and subnational governments, and smaller national governments. Revenue decentralization leads to larger subnational governments, but it reduces national government size by more than it increases subnational government size, and therefore leads to a smaller aggregate government. Vertical imbalance is the only fiscal variable that can increase the sizes of public sector at all levels (subnational, national, and aggregate).

Controlling for political and institutional variables, the analysis shows that a less independent central bank is associated with larger governments at both subnational and national levels, and hence larger aggregate government. When using expenditure decentralization and vertical imbalance as decentralization measures, elected subnational government seems effective in restraining the public sector at subnational level. In the regression using revenue decentralization, 
an elected subnational government is likely to expand, although the effect is insignificant.

The feasible generalized least squares (FGLS) estimations also indicate that, in general, borrowing constraints have no significant effect on government size at any level (subnational, national and aggregate). Federal states, with a more decentralized regime than a unitary one, tend to have a smaller overall public sector.

\section{Acknowledgments}

We thank two referees and Jan Brueckner (the editor) for very detailed suggestions in revising this paper. Of course, we are solely responsible for any remaining errors.

\section{References}

[1] V. Tanzi, Fiscal federalism and decentralization: A review of some efficiency and macroeconomic aspects, in: Annual World Bank Conference on Development Economics, 1995, The World Bank, Washington, DC, 1996.

[2] H. Davoodi, H. Zou, Fiscal decentralization and economic growth: A cross-country study, Journal of Urban Economics 43 (1998) 244-257.

[3] T. Zhang, H. Zou, Fiscal decentralization, public spending and economic growth in China, Journal of Public Economics 67 (1998) 221-240.

[4] R. Bahl, J. Linn, Urban Public Finance in Developing Countries, Oxford University Press, New York, 1992.

[5] A. Shah, The Reform of Intergovernmental Fiscal Relations in Developing and Emerging Market Economies, The World Bank, Washington, DC, 1994.

[6] K. Fukasaku, L.R. de Mello Jr., Fiscal decentralization and macroeconomic stability: The experience of large developing and transition economies, in: K. Fukasaku, R. Hausmann (Eds.), Democracy, Decentralization and Deficits in Latin America, IDB-OECD, Paris and Washington, 1997.

[7] R. Inman, D. Rubinfeld, Rethinking federalism, Journal of Economic Perspectives 4 (1997) 433464.

[8] E. Stein, Fiscal decentralization and government size in Latin America, in: K. Fukasaku, R. Hausmann (Eds.), Democracy, Decentralization and Deficits in Latin America, IDB-OECD, 1997.

[9] G. Brennan, J.M. Buchanan, Power to Tax, Cambridge University Press, 1980.

[10] W. Oates, Searching for Leviathan: A reply and some further reflections, American Economic Review 79 (1989) 578-583.

[11] C. Tiebout, A pure theory of local expenditures, Journal of Political Economy 64 (1956) 416424.

[12] W. Oates, Fiscal Federalism, Harcourt Brace Jovanovich, New York, 1972.

[13] R. Prud'homme, On the dangers of decentralization, World Bank Research Observer 10 (1995) 201-220.

[14] W. Oates, Searching for Leviathan: An empirical analysis, American Economic Review 75 (1985) 748-757. 
[15] M.A. Nelson, Searching for Leviathan: Comment and extension, American Economic Review 77 (1987) $198-204$.

[16] J.S. Zax, Is there a Leviathan in your neighborhood? American Economic Review 79 (1989) $560-567$.

[17] J. Brueckner, Fiscal decentralization in developing countries: The effects of local corruption and tax evasion, Annals of Economics and Finance 1 (2000) 1-18.

[18] M. Marlow, Fiscal decentralization and government size, Public Choice 56 (1988) 259-269.

[19] P. Grossman, Fiscal decentralization and government size: An extension, Public Choice 62 (1989) 63-69.

[20] J. Ehdaie, 1994, Fiscal decentralization and the size of government, Policy Research Department, The World Bank, Washington, DC, 1994.

[21] F. Fornasari, S.B. Webb, H. Zou, The macroeconomic impact of decentralized spending and deficits: International evidence, Annals of Economics and Finance 1 (2000) 403-433.

[22] International Monetary Fund (IMF), Government Financial Statistics, various issues.

[23] A. Cukierman, S.B. Webb, Political influence of the central bank: International evidence, World Bank Economic Review 3 (1995) 397-423.

[24] Europa World Yearbook, Europa Publications Limited, London, England, 1995.

[25] Economist Intelligence Unit, Country Reports, various issues.

[26] T. Ter-Minassian, J. Craig, Control of subnational borrowing, in: T. Ter-Minassian (Ed.), Fiscal Federalism in Theory and Practice, IMF, 1997.

[27] Inter-American Development Bank (IDB), Can decentralized democracy deliver fiscal stability? The Institutional Dimension, Washington, DC, 1997.

[28] World Bank, World Development Indicators, Washington, DC, 1997. 